\title{
Analisa Eksergi PLTU Berbahan Bakar Sampah Padat Kota Kapasitas 600 Ton per Hari
}

\section{Exergy Analysis of Municipal Solid Waste Fired Steam Power Plant with Capacity of 600 Ton per Day}

\author{
AMIRAL AZIZ \\ Balai Besar Teknologi Konversi Energi - BPPT Gedung 625 \\ Kluster Energi Puspiptek Serpong Tangerang Selatan \\ Email : amiral.aziz@bppt.go.id
}

\begin{abstract}
Exergy analysis was conducted in evaluating the performance of Muncipal Solid Waste Fired Steam Power Plant (PLTSa) to determine the locations and quantities of exergy losses. Wastes and exergy destructions in different processes of the plant were also been calculated. Total exergy available at incinerator input was 60.560,54 kW, consisted of 58.242,45 kW in MSW and 2.318,08 kW in the combustion air. The burning of 600 ton per day MSW in the PLTSa produced 8.482,83 kW Net Electric Power, accounted for $14,01 \%$ of the overall exergy efficiency of the power plant. The plant produced electrical energy $59.447 .673 \mathrm{kWh} /$ year and reduced 240.900ton MSW/year, thus contributing to $\mathrm{CO}_{2}$ emission reduction. Exergy efficiency of the turbine generator and condenser were 86,21\% and 78,48\% respectively. PLTSa component with the largest exergy destructions was incinerator-boiler (56,53\%), far exceeded the turbine generator (8,69\%), and condenser (3,79\%).
\end{abstract}

Keywords: Exergy, Exergy Destruction, Steam Power Plant, Muncipal Solid Waste (MSW), Exergy Efficiency.

\begin{abstract}
ABSTRAK
Analisa eksergi PLTSa telah dilakukan untuk mengetahui lokasi dan jumlah kerugian eksergi. Limbah dan destruksi eksergi dalam proses yang berbeda telah diindikasikan. Hasil yang diperoleh menunjukkan bahwa total eksergi yang tersedia pada input Incenerator adalah $60.560,54 \mathrm{~kW}$. Nilai ini terdiri dari $58.242,45 \mathrm{~kW}$ yang terkandung dalam MSW dan 2.318,08 kW dalam udara pembakaran. Pembakaran 600 ton per hari MSW pada sistem PLTSa menghasilkan 8.482,83 kW daya listrik bersih dan $14,01 \%$ efisiensi eksergi keseluruhan pembangkit. Pembangkit menghaslkan energi listrik sebesar 59.447 .673 $\mathrm{kWh} /$ tahun dan mengurangi timbunan sampah sebanyak 240.900 ton MSW/tahun, sehingga berkontribusi dalam mengurangi emisi $\mathrm{CO}_{2}$. Efisiensi eksergi dari sistem turbin generator dan sistem kondensor masing-masing adalah $86,21 \%$ dan $78,48 \%$. Komponen PLTSa dimana terjadi destruksi eksergi yang terbesar berturut-turut adalah pada sistem Insinerator-boiler sebesar $56,53 \%$, sistem turbine - generator $8,69 \%$ dan sistem kondensor $3,79 \%$.
\end{abstract}

Kata kunci: Eksergi, Destruksi Eksergi, PLTSa, Sampah Padat Kota (MSW), Efisiensi Eksergi

\section{PENDAHULUAN}

\subsection{Latar Belakang}

Selama tahun 2017 produksi rata-rata sampah DKI Jakarta adalah $7.164,53$ ton/hari yang dihasilkan oleh 2.710 .617 rumah tangga atau 10.374.235 penduduk DKI Jakarta. Dalam kurun 5 tahun terakhir, produksi sampah mengalami peningkatan yaitu dari $6.513,85$ ton/hari pada tahun 2013 menjadi 7.164,53 ton/hari pada tahun $2017^{(1)}$. Hal ini seiring dengan laju pertumbuhan penduduk dalam periode tersebut sebesar $0,94 \%$ per tahun.

Pertumbuhan produksi sampah kota DKI Jakarta diperkirakan masih akan meningkat di tahun - tahun mendatang dimana pertumbuhan jumlah penduduk menjadi faktor utama pertumbuhan produksi sampah kota. Dari produksi sampah kota DKI Jakarta sebesar 7.164,53 ton/hari (tahun 2017) seluruhnya dibuang di tempat pembuangan sampah terpadu (TPST) Bantar Gebang. Volume sampah sebesar ini tidak mengalami proses reduksi volume sejak dari timbulan sampah, tempat penampungan sementara, stasiun transfer hingga TPST Bantar Gebang. Kebijakan 3R (Reduce-ReuseRecycle) belum berjalan dengan baik karena persepsi masyarakat bahwa sampah adalah barang sisa tidak berguna dan bukan sumberdaya yang bisa dimanfaatkan. Lokasi 
TPST Bantar Gebang merupakan lahan yang berada di luar wilayah DKI Jakarta, sehingga ada ketergantungan dengan pihak-pihak yang berkepentingan di luar wilayah DKI Jakarta. Pengangkutan sampah dari stasiun pengumpulan menuju TPST yang jauh lokasinya menimbulkan persoalan transportasi tersendiri. Selain itu, pengelolaan sampah kota yang hanya bertumpu pada TPA akan membutuhkan lahan yang luas dan terus menerus harus diperluas seiring dengan timbulnya sampah setiap saat. Oleh sebab itu sudah saatnya diaplikasikan sistim pengelolaan sampah perkotaan yang mampu mengurangi sampah secara cepat dan signifikan serta ramah lingkungan yaitu Waste to Energy Plant (WTE Plant) atau Pusat Listrik Tenaga Sampah (PLTSa) dengan mengubah energi panas hasil pembakaran menjadi energi listrik. Dengan penerapan teknologi PLTSa di DKI Jakarta maka ada beberapa manfaat yang diperoleh yaitu:

a. Hilangnya ketergantungan pada pihak-pihak di luar wilayah DKI Jakarta karena kebutuhan lahan setiap instalasi PLTSa relatif kecil dan dapat dibangun secara tersebar.

b. Terkuranginya persoalan transportasi angkutan sampah karena lokasi pengolahan sampah yang tersebar.

c. Terkuranginya volume sampah padat menjadi residu akhir (limbah abu) secara signifikan sekaligus mengubah menjadi energi listrik yang akan meningkatkan peran listrik berbasis energi terbarukan.

d. Terkelolanya sampah perkotaan menjadi lebih efisien dengan mengikutsertakan masyarakat dan swasta karena ada perubahan tanggungjawab treatment sampah yakni pemerintah sebagai regulator dan swasta sebagai operator.

Berdasarkan pertimbangan-pertimbangan di atas dan mengingat pada Peraturan Presiden No. 35 tahun 2018(2) dan Peraturan Menteri ESDM No. 44 tahun 2015(3), maka Konsorsium antara suatu BUMD dan Swasta Nasional menyatakan keinginan untuk ikut serta dalam pengelolaan sampah kota DKI Jakarta dan mengembangkan PLTSa di lokasi ITF Cakung Cilincing sebanyak 2 unit dengan kapasitas incinerator perunit 600 ton per hari. Tulisan ini menampilkan beberapa hasil analisa eksergi yang telah dilakukan pada Sistem Pembangkit Listrik Tenaga Sampah (PLTSa) berkapasitas 600 ton/hari yang bertujuan untuk mengidentifikasi lokasi dan proses dimana terjadi kerugian, kehilangan dan kerusakan eksergi serta menyarankan langkah-langkah yang dapat diambil untuk mengurangi kerugian eksergi.

\subsection{Tujuan Penelitian}

Studi ini bertujuan untuk menentukan efisiensi eksergi PLTSa berkapasitas 600 ton/hari dan mengidentifikasi lokasi dan proses dimana terjadi kerugian, kehilangan dan kerusakan eksergi serta menyarankan langkah-langkah yang dapat diambil untuk mengurangi kerugian eksergi.

\section{BAHAN DAN METODE}

\subsection{Diskripsi PLTSa 600 ton/hari}

Lokasi rencana PLTSa Cakung Cilincing terletak di Km 6 Jalan Tol Lingkar Luar Jakarta 1 (JORR 1) seperti dapat dilihat pada gambar1. Lingkungan lahan terdiri dari lahan industri, pergudangan, komersial dan kawasan perumahan. Disisi timur terdapat lokasi rencana gardu induk PLN untuk distribusi ke area Jakarta Garden City, sedangkan di sisi Timur dan Selatan terdapat saluran drainase alam. Secara administrasi, lahan terletak di wilayah Kelurahan Cakung Timur, Kecamatan Cakung, Jakarta Timur

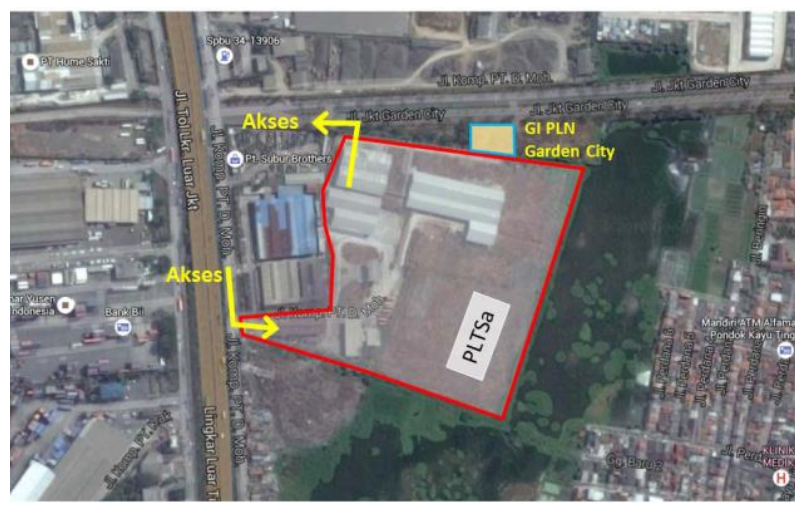

Gambar 1. Lokasi Rencana PLTSa Cakung Cilincing

Gambar 2 memperlihatkan diagram alir Pembangkit Listrik Tenaga Sampah (PLTSa). Incinerator atau ruang pembakaran akan menggunakan jenis stoker dengan pilihan tumbling grate atau reversible grate. Penggunaan grate mekanis tersebut untuk mendapatkan efisiensi pembakaran yang tinggi dan pembakaran sempurna serta menahan flue gas beberapa detik dalam ruang bakar bertemperatur $800^{\circ} \mathrm{C} \sim 850^{\circ} \mathrm{C}$ untuk mengurangi sebanyak mungkin dioxin. 


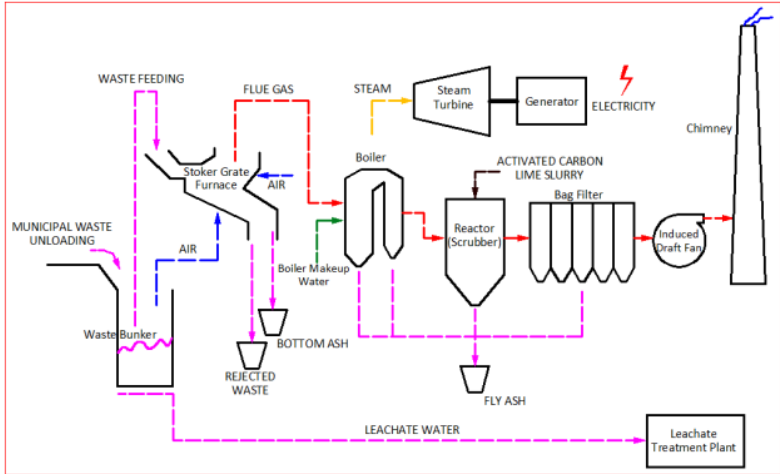

Gambar 2. Diagram Alir Pembangkit Listrik Tenaga Sampah

PLTSa Cakung Cilincing akan menggunakan 2 unit incinerator berkapasitas masing-masing 600 ton/hari. Boiler (steam generator) merupakan jenis sirkulasi tertutup dengan konfigurasi 1 unit higher pressure heater (HP heater), 1 unit deaerator, 1 unit lower pressure heater (LP heater). Tabel 1 memperlihatkan data spesifikasi teknis desain dari pembanglkit.

Flue gas treatment system akan terdiri dari scrubber system, activated carbon injection system, dan Bagfilter system. Disamping itu terdapat ammonia injection system yang dipasang di daerah "post combustion" dari furnace untuk menetralkan $\mathrm{NOx}^{(4)}$. Lime slurry sub system berfungsi untuk membuat lime powder menjadi lime slurry yang kemudian diinjeksikan ke scrubber untuk menetralkan gas-gas yang bersifat asam. Scrubber dan rotating atomizer adalah reactor untuk proses netralisasi flue gas. Activated carbon injection system digunakan untuk mengikat kandungan $\mathrm{Hg}$ dan dioxin yang terdapat pada flue gas. Bagfilter system digunakan untuk menangkap fly ash dan partikel-partikel lain. Induce draft fan yang dipasang setelah Bagfilter berfungsi untuk mengalirkan flue gas yang sudah bersih ke cerobong (stack) dan menjaga tekanan negative di dalam reaktor dan Bagfilter. Hasil Analisa Proksimat, Analisa Ultimat MSW Jakarta dan Nilai Panas Bawah (Low Heat Nilai) untuk 6 sample yang dilakukan pada laboratorium Buangan Padat dan B3 diberikan masing-masinig pada Tabel 2 , 3 dan 4.

Tabel 1. Spesifikasi Teknis Desain PLTSa Cakung Cilincing.

\begin{tabular}{|c|c|}
\hline Peralatan & Spesifikasi Teknis \\
\hline Insinerator & Tipe Grate, Kapasitas 600 ton/hari \\
\hline \multirow[t]{3}{*}{ Boiler } & Jenis: Ketel Pipa Air - Sirkulasi Alamiah \\
\hline & Kapasitas Uap : $11,4 \mathrm{~kg} / \mathrm{s}$ \\
\hline & Kondisi uap: $410^{\circ} \mathrm{C} \times 46$ bar \\
\hline \multirow[t]{2}{*}{ Turbin Uap- Generatoo } & Turbin Uap Condensing + generator. \\
\hline & Kapasitas Generator $10 \mathrm{MW}$ \\
\hline \multirow{4}{*}{$\begin{array}{l}\text { Sistem Pengilagan Gas } \\
\text { Buang }\end{array}$} & Jenis Pengumpul Debu: Bag Filter \\
\hline & Metode penghapusan HCL, SOx: Sistem Tipe Semi \\
\hline & $\begin{array}{l}\text { Sistem Tipe Kering (sodium bicarbonate injection) } \\
\text { Metoda De-NOx: SNCR+SCR }\end{array}$ \\
\hline & $\begin{array}{l}\text { Metode penghilangan dioksin, senyawa } \mathrm{Hg} \text { : injeksi } \\
\text { karbon aktif }\end{array}$ \\
\hline
\end{tabular}

Tabel 2. Analisa Proksimat MSW Jakarta

\begin{tabular}{ccccc}
\hline Elemen & Kadar Air & $\begin{array}{c}\text { Kadar } \\
\text { Abu }\end{array}$ & Kadar Volatile & $\begin{array}{c}\text { Fixed } \\
\text { Carbon }\end{array}$ \\
\hline Sample 1 & 65,62 & 13,09 & 83,22 & 3,69 \\
\hline Sample 2 & 68,84 & 13,77 & 82,73 & 3,50 \\
\hline Sample 3 & 61,05 & 20,36 & 78,24 & 1,40 \\
\hline Sample 4 & 39,97 & 37,62 & 50,61 & 11,77 \\
\hline Sample 5 & 58,01 & 32,20 & 64,72 & 3,08 \\
\hline Sample 6 & 56,20 & 28,44 & 63,52 & 8,04 \\
\hline
\end{tabular}


Tabel 3. Analisa Ultimat MSW Jakarta

\begin{tabular}{cccccc}
\hline Elemen & $\mathrm{C}$ & $\mathrm{H}$ & $\mathrm{O}$ & $\mathrm{N}$ & $\mathrm{S}$ \\
\hline Sample 1 & 63,50 & 6,58 & 29,49 & 0,44 & \\
\hline Sample 2 & 64,61 & 6,53 & 28,42 & 0,45 & \\
\hline Sample 3 & 55,15 & 6,04 & 38,28 & 0,54 \\
\hline Sample 4 & 38,60 & 4,10 & 56.20 & 1.09 \\
\hline Sample 5 & 45,23 & 4,95 & 49,02 & 0,81 \\
\hline Sample 6 & 48,77 & 5,06 & 45,34 & 0,83
\end{tabular}

Tabel 4. LHV MSW Jakarta

\begin{tabular}{cclc}
\hline Elemen & LHV & Satuan & \multicolumn{1}{c}{ Metoda } \\
\hline Sample 1 & $1.857,9$ & $\mathrm{kkal} / \mathrm{kg}$ & ASTM D240 (2009) \\
\hline Sample 2 & $1.471,7$ & $\mathrm{kkal} / \mathrm{kg}$ & ASTM D240 (2009) \\
\hline Sample 3 & $1.989,9$ & $\mathrm{kkal} / \mathrm{kg}$ & ASTM D240 (2009) \\
\hline Sample 4 & $1.908,5$ & $\mathrm{kkal} / \mathrm{kg}$ & ASTM D240 (2009) \\
\hline Sample 5 & $1.672,0$ & $\mathrm{kkal} / \mathrm{kg}$ & ASTM D240 (2009) \\
\hline Sample 6 & $1.658,8$ & $\mathrm{kkal} / \mathrm{kg}$ & ASTM D240 (2009) \\
\hline Rata-rata & 1.759 .8 & $\mathrm{kkal} / \mathrm{kg}$ &
\end{tabular}

Sistem PLTSa ini disederhanakan menjadi volume kontrol yang menggambarkan aliran eksergi masuk dan aliran eksergi keluar untuk setiap aliran proses yang berbeda. Proses diasumsikan dalam keadaan tunak (steady state). Output eksergi yang diinginkan (output kerja bersih) dibandingkan dengan eksergi input yang diperlukan (efisiensi rasional). Tata letak proyek telah dirancang dan dilengkapi dengan skematik diagram alir untuk sistem total dan setiap subsistem (proses). Dalam studi ini digunakan MSW sebagai bahan bakar dimana 6 sample sampah di sekitar daerah Cakung-Cilincing diambil dan dianalisa di laboratorium yang meliputi komposisi kimia, analisa Proksimat dan Ultimat beserta Nilai Panas Bawah (LHV) dengan LHV rata-rata adalah $1.758,9 \mathrm{kkal} / \mathrm{kg}$.

Data yang relevan diperoleh dan diproses dengan menggunakan spread sheet Excel. Persamaan untuk analisis setiap subsistem berasal dan model yang dibuat dengan bantuan EES Software (Engineering Equation Solver). Nilai entalpi dan entropi untuk tekanan dan temperatur fluida diketahui ditentukan dengan menggunakan tabel sifat termodinamika untuk air pada buku
Fundamental of Engineering Thermodynamic ${ }^{(13)}$. Dengan memasukkan data-data lapangan, spesifikasi peralatan dan parametr perancangan, kesetimbangan eksergi dan evaluasi kinerja setiap sub sistem dan sistem keseluruhan dilakukan. Dalam analisa eksergi diperlukan parameter standar yang digunakan sebagai referensi. Tekanan dan temperatur standar di Cakung Jakarta Timur adalah $1 \mathrm{~atm}=101,325 \mathrm{kPa}$ dan $25^{\circ} \mathrm{C}$. Dengan demikian melaui tabel sifat udara didapatkan entalpi udara lingkungan $h_{0}=104,93$ $\mathrm{kJ} / \mathrm{kg}$ dan entropi lingkungan $\mathrm{s}=0,367 \mathrm{~kJ} / \mathrm{kg} \cdot \mathrm{K}^{(13)}$. Asumsi yang dibuat dalam analisa eksergi PLTSa ini adalah :

1. Sistem dan proses dinyatakan sebagai volume kontrol dalam keadaan tunak.

2. Penurunan tekanan pada jalur pemipaan diabaikan.

3. Eksergi kinetik, potensial dan kimia diabaikan.

\subsection{Konsep Dasar Analisa Eksergi}

Gambar 3 menggambarkan aliran eksergi melalui sistem atau proses. Salah satu kegunaan utama dari konsep eksergi adalah keseimbangan 
eksergi dalam analisis sistem termal. Keseimbangan eksergi (analisis eksergi) dapat dipandang sebagai pernyataan hukum degradasi energi. Evaluasi yang teliti terhadap proses termal dengan menggunakan analisis eksergy memungkinkan identifikasi sumber ke tidak efisienan dan limbah yang menyebabkan perbaikan desain dan penghematan yang dihasilkan. Analisis eksergi adalah alat untuk identifikasi jenis, lokasi dan besarnya kerugian termal. Identifikasi dan kualifikasi kerugian ini memungkinkan untuk evaluasi dan perbaikan desain sistem termal.

Dengan metode analisis eksergi, dapat menunjukkan kualitas dan kuantitas kerugian panas dan lokasi degradasi energi (mengukur dan mengidentifikasi penyebab degradasi energi). Sebagian besar kasus ketidak sempurnaan termodinamika tidak dapat dideteksi dengan analisis energi. Proses tertentu seperti throttling, transfer panas, ekspansi dan gesekan tidak termasuk kerugian energi tetapi mereka menurunkan kualitas energi dan kemampuannya untuk melakukan kerja dan oleh karena itu termasuk kerugian eksergi

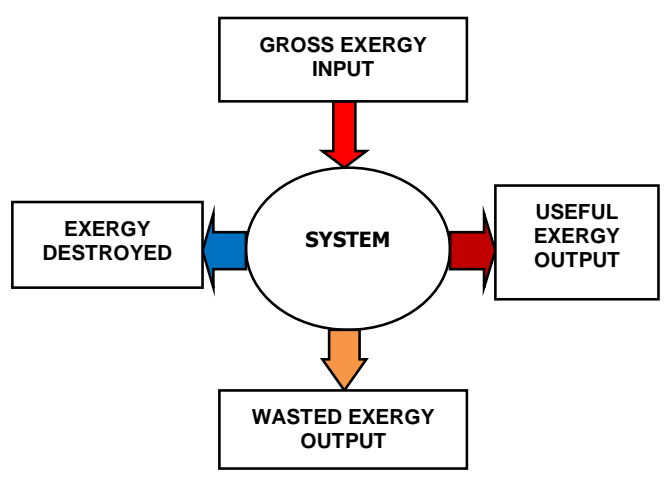

Gambar 3. Aliran eksergi melalui sistem

Untuk aliran materi, total aliran eksergi, dapat dinyatakan sebagai $(5,12)$ :

$$
E_{\text {total. }}=E_{K E}+E_{P E}+E_{P H}+E_{C H}
$$

Keterangan :

$E_{K E}=$ eksergi kinetik (kW)

$E_{P E}=$ eksergi potensial $(\mathrm{kW})$

$E_{P H}=$ eksergi fisika $(\mathrm{kW})$

$E_{C H}=$ eksergi kimia $(\mathrm{kW})$

Pada penelitian ini analisa eksergi akan mengabaikan eksergi kinetik dan eksergi potensial serta perubahan eksergi akibat pengaruh nuklir, maknetik, listrik dan interpasial sehingga total eksergi pada aliran hanya akan terdiri dari 2 komponen utama, yaitu eksergi fisika dan eksergi kimia $^{(5,15)}$ adalah :

$$
E_{\text {total. }}=E_{P H}+E_{C H}
$$

Eksergi fisika merupakan eksergi yang berhubungan dengan perubahan tekanan dan temperatur dalam aliran. Eksergi fisika dapat dihitung menggunakan persamaan berikut ${ }^{(5,12)}$ :

$$
E_{P H}=m_{i} \times\left[\left(h_{i}-h_{0}\right)-T_{0} \times\left(s_{i}-s_{0}\right)\right] .
$$

Keterangan :

$i$ = menunjukkan titik keadaan

0 = keadaan lingkungan

$m$ = laju aliran $(\mathrm{kg} / \mathrm{s})$

$h=$ entalpi $(\mathrm{kJ} / \mathrm{kg})$

$s=$ entropi $(\mathrm{kJ} / \mathrm{kg} . \mathrm{K})$

$T=$ temperature $(\mathrm{K})$.

Eksergi kimia merupakan eksergi yang berhubungan dengan perubahan senyawa kimia. Eksergi kimia dapat dihitung menggunakan persamaan berikut ${ }^{(5,10,12)}$ :

$$
E_{C H}=m \times \frac{\varepsilon_{C H}^{o}}{M} .
$$

Keterangan:

$E_{C H} \quad=$ eksergi kimia $(\mathrm{kW})$

$\mathrm{m} \quad$ = laju aliran fluida $(\mathrm{kg} / \mathrm{s})$

$\varepsilon^{\circ} \mathrm{CH} \quad=$ nilai eksergi kimia molar standar $(\mathrm{kJ} / \mathrm{kmol})$

$\mathrm{M}=$ Massa Molekul $(\mathrm{kg} / \mathrm{kmol})$

Nilai eksergi kimia molar stándar $\varepsilon^{\circ} \mathrm{CH}$ untuk beberapa zat dapat dilihat pada tabel 4 .

Tabel 4. Eksergi kimia molar $\varepsilon^{\circ}{ }_{C H} \quad(\mathrm{~kJ} / \mathrm{kgmol})$ beberapa zat ${ }^{(12)}$.

\begin{tabular}{lcc}
\hline Zat & Formula & $\mathcal{E}^{\circ} \mathrm{CH}$ \\
\hline Oksigen & $\mathrm{O}_{2}(\mathrm{~g})$ & 3970 \\
\hline Nitrogen & $\mathrm{N}_{2}(\mathrm{~g})$ & 720 \\
\hline $\begin{array}{l}\text { Karbon } \\
\text { Dioksida }\end{array}$ & $\mathrm{CO}_{2}(\mathrm{~g})$ & 20140 \\
\hline Air & $\mathrm{H}_{2} \mathrm{O}(\mathrm{g})$ & 11710 \\
\hline $\begin{array}{l}\text { Sulfur } \\
\text { Dioksida }\end{array}$ & $\mathrm{SO}_{2}(\mathrm{~g})$ & 303500 \\
\hline
\end{tabular}

Untuk volume kontrol, persamaan kesetimbangan eksergi dapat dinyatakan dengan:

$$
E_{\text {input }}=E_{\text {desired }}+E_{\text {waste }}+E_{\text {destroyed }} \text {. }
$$

Keterangan :

$E_{\text {input }}=$ eksergi total masuk volume control.

$E_{\text {desired }}=$ eksergi total yang diinginkan (net work output);

$E_{\text {waste }} \quad=$ jumlah eksergi selain yang diinginkan .

$E_{\text {destroyed }}=$ jumlah kerugian eksergi system (irreversibilitas)

Edestroyed secara langsung berhubungan dengan generasi entropi yang dinyatakan dengan persamaan (5): 


$$
E_{\text {destroyed }}=T_{0} \times S \text {. }
$$

Kriteria kinerja sistem eksergi tergantung pada laju transfer eksergi masuk dan keluar volume kontrol. Ukuran yang paling tepat dalam menentukan kriteria kinerja adalah "rational exergy efficiency" yaitu rasio antara jumlah eksergi keluar yang diinginkan (desired exergy output) dengan jumlah eksergi masu ${ }^{(5)}$

$$
\eta_{\varepsilon}=\frac{E_{\text {desired }}}{E_{\text {input }}}
$$

Persamaan untuk menghitung rational exergy efficiency untuk beberapa komponen seperti boiler, turbin dan pompa diberikan pada Tabel $5^{(5)}$

Tabel 5. Persamaan Rational exergy efficiency

\begin{tabular}{|c|c|c|c|c|c|}
\hline Component & $\begin{array}{l}\text { Compressor, } \\
\text { Pump, or Fan }\end{array}$ & $\begin{array}{l}\text { Turbine or } \\
\text { Expander }\end{array}$ & Heat Exchanger & $\begin{array}{l}\text { Gasifier or } \\
\text { Combustion } \\
\text { Chamber }\end{array}$ & Boiler \\
\hline Schematic & $\dot{\mathrm{w}}_{3}$ & $V_{4}^{1} \dot{w}_{2}$ & Hot stream & 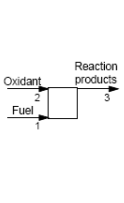 & 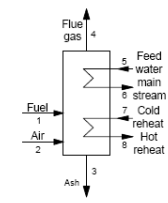 \\
\hline $\begin{array}{l}\text { Exergy rate of } \\
\text { product, } E p\end{array}$ & E2-E1 & w & E2-E1 & E3 & $(E 6-E 5)+(E 8-E 7)$ \\
\hline $\begin{array}{l}\text { Exergy rate of } \\
\text { fuel, } E f\end{array}$ & W & E1-E2-E3 & E3-E4 & $\mathrm{E} 1+\mathrm{E} 2$ & $(E 1-E 2)-(E 3+E 4)$ \\
\hline $\begin{array}{l}\varepsilon=\text { Rational } \\
\text { exergy } \\
\text { efficiency }\end{array}$ & $\varepsilon=\frac{E 2-E 1}{W}$ & $\varepsilon=\frac{W}{E 1-E 2-E 3}$ & $\varepsilon=\frac{E 2-E 1}{E 3-E 4}$ & $\varepsilon=\frac{E 3}{E 1+E 2}$ & $\varepsilon=\frac{(E 6-E 5)+(E 8-E 7)}{(E 1-E 2)-(E 3+E 4)}$ \\
\hline
\end{tabular}
beberapa peralatan Mekanikal(5)

\subsection{Analisa Eksergi PLTSa}

\subsubsection{Proses pembakaran MSW didalam Insenerator - Boiler (HRSG)}

Persamaan kesetimbangan massa proses pembakaran didalam Sistem Insenerator - Boiler ditunjukkan pada gambar $5^{(18)}$.

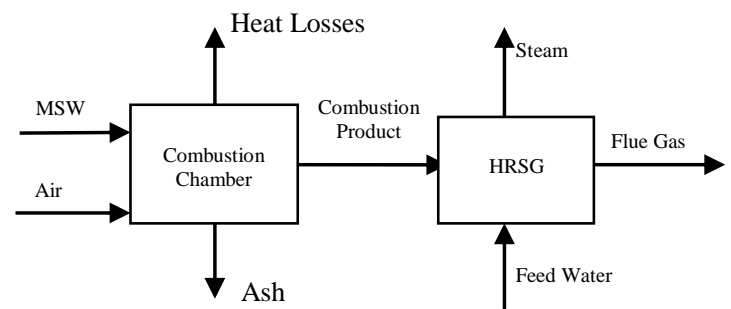

Gambar 5. Sistem Insinerator-Boiler (HRSG)

$m_{M S W}+m_{\text {air }}=m_{f g}+m_{\text {ash }}+m_{\text {moisture }}$

Massa udara teoritis (stochimetric) yang dibutuhkan untuk membakar $1 \mathrm{~kg} \mathrm{MSW}$ adalah ${ }^{(6,16)}$ $\left(m_{a}\right)_{t h, v, d}=\frac{8,66 \mathrm{C}+7,94 \mathrm{H}_{2}+0,998 \mathrm{~S}-\mathrm{O}_{2}}{0,232}$

Persentase kelebihan udara $\lambda$ (Excess air) diberikan oleh persamaan ${ }^{(5,15)}$ :

$\lambda=\frac{\left(m_{a} / m_{f}\right)_{a k t}-\left(m_{a} / m_{f}\right)_{t h}}{\left(m_{a} / m_{f}\right)_{t h}}=\frac{(V a)_{a k t}-(V a)_{t h}}{(V a)_{t h}}$

Massa udara aktual yang dibutuhkan untuk pembakaran $1 \mathrm{~kg}$ MSW dengan presentase udara lebih $\lambda$ (excess air) adalah :

$$
\left(m_{a}\right)_{a c t, d}=(1+\lambda) \times\left(m_{a}\right)_{t h}
$$

Massa gas hasil pembakaran $m_{F G}$ (flue gas) 1 kg MSW seperti diberikan pada persamaan 12 sampai dengan $16^{(5,15)}$ :

$m_{\mathrm{FG}}=m_{\mathrm{CO} 2}+m_{\mathrm{SO} 2}+m_{\mathrm{H} 2 \mathrm{O}}+m_{\mathrm{N} 2}+m_{\mathrm{O} 2}$

Di mana :

$m_{\mathrm{CO} 2}, m_{\mathrm{SO} 2}, m_{\mathrm{H} 2 \mathrm{O}}, m_{\mathrm{N} 2}$ dan $m_{\mathrm{O} 2}$ masingmasing adalah massa dari $\mathrm{CO}_{2}, \mathrm{SO}_{2}, \mathrm{H}_{2} \mathrm{O}, \mathrm{N}_{2}$ dan $\mathrm{O}_{2}$ yang terkandung dalam gas hasil pembakaran. Massa gas asap basah $\left(m_{F G}\right)_{\text {wet }}$ adalah :

$\left(m_{F G}\right)_{\text {wet }}=1+\left(m_{a}\right)_{a c t, d}-m_{a}$

Analisa gas asap basah untuk karbon dioksida $\left(\mathrm{CO}_{2}\right)_{\text {wet, }}$ sulfur dioksida $\left(\mathrm{SO}_{2}\right)_{\text {wet, }}$ Air $\left(\mathrm{H}_{2} \mathrm{O}\right)_{\text {wet }}$, oksigen $\left(\mathrm{O}_{2}\right)_{\text {wet }}$ dan nitrogen $\left(\mathrm{N}_{2}\right)_{\text {wet }}$ adalah sebagai berikut :

$$
\begin{aligned}
& \left(\mathrm{CO}_{2}\right)_{\text {wet }}=\frac{m_{\mathrm{CO} 2}}{\left(m_{F G}\right)_{w e t}} \ldots . .(14 . a) \\
& \left(\mathrm{SO}_{2}\right)_{\text {wet }}=\frac{m_{S O 2}}{\left(m_{F G}\right)_{w e t}} \ldots . .(14 . b) \\
& \left(\mathrm{H}_{2} \mathrm{O}\right)_{\text {wet }}=\frac{m_{H 2 O}}{\left(m_{F G}\right)_{w e t}} \ldots . .(14 . c) \\
& \left(\mathrm{O}_{2}\right)_{\text {wet }}=\frac{m_{O 2}}{\left(m_{F G}\right)_{w e t}} \ldots . .(14 . d) \\
& \left(\mathrm{N}_{2}\right)_{\text {wet }}=\frac{m_{N 2}}{\left(m_{F G}\right)_{w e t}} \ldots . .(14 . e)
\end{aligned}
$$

Massa gas asap kering $\left(m_{F G}\right)$ dry adalah :

$$
\left(m_{F G}\right)_{d r y}=\left(m_{F G}\right)_{w e t}-\left(m_{H 2 O}\right)
$$

Analisa gas asap kering untuk karbon dioksida $\left(\mathrm{CO}_{2}\right)_{\text {dry }}$, sulfur dioksida $\left(\mathrm{SO}_{2}\right)_{\text {dry }}$, oksigen $\left(\mathrm{O}_{2}\right)_{\text {dry }}$ dan nitrogent $\left(\mathrm{N}_{2}\right)_{\text {dry }}$ adalah sebagai berikut : 


$$
\begin{aligned}
& \left(\mathrm{CO}_{2}\right)_{d r y}=\frac{m_{C O 2}}{\left(m_{F G}\right)_{d r y}} \ldots . .(16 . a) \\
& \left(S O_{2}\right)_{d r y}=\frac{m_{S O 2}}{\left(m_{F G}\right)_{d r y}} \ldots . .(16 . b) \\
& \left(O_{2}\right)_{d r y}=\frac{m_{O 2}}{\left(m_{F G}\right)_{d r y}} \ldots . .(16 . c) \\
& \left(N_{2}\right)_{d r y}=\frac{m_{N 2}}{\left(m_{F G}\right)_{d r y}} \ldots . .(16 . d)
\end{aligned}
$$

Neraca energi pada incinerator dan boiler (HRSG) diberikan oleh persamaan:

$$
\begin{aligned}
& Q_{F}+Q_{A I R}=Q_{F G}+Q_{S}+Q_{U F} \ldots .(17 . a) \\
& Q_{A I R}=m_{A I R} \times C p_{A I R} \times\left(T_{A I R}-T_{0}\right) \text {. } \\
& Q_{F}=m_{M S W} \times L H V_{M S W} \ldots(17 . c) \\
& Q_{F G}=m_{F G} \times C p_{F G} \times\left(T_{F G}-T_{0}\right) \ldots . .(17 . d) \\
& Q_{\text {STEAM }}=m_{\text {STEAM }} \times\left(h_{S T}-h_{F W}\right) \ldots .(17 . e) \\
& Q_{U F}=m_{A S H} \times L H V_{M S W}
\end{aligned}
$$

$m_{M S W} \cdot L H V_{M S W}+$ ma.Cp $p_{a}\left(T_{a}-T_{0}\right)=$

$m_{F G} \cdot C p_{F G}\left(T_{F G}-T_{0}\right)+m_{A S H} \cdot L H V+m_{M S T}\left(h_{S T}-h_{F W}\right)$ (17.g)

Persamaan neraca eksergi dari system Insinerator-HRSG sebagai berikut :

$$
\begin{aligned}
& E_{M S W}+E_{A I R}+E_{F W}=E_{S T}+E_{F G}+E_{A S H}+ \\
& E_{V M}+. E_{H R S G} \ldots \ldots \ldots \ldots . . . .(18)
\end{aligned}
$$

Keterangan :

$$
\begin{array}{ll}
\mathrm{E}_{\mathrm{MSW}} & =\text { eksergi bahan bakar MSW (MW) } \\
\mathrm{E}_{\mathrm{AIR}} & =\text { eksergi udara pembakaran (MW) } \\
\mathrm{E}_{\mathrm{FW}} & =\text { eksergi feed water (MW) } \\
\mathrm{E}_{\mathrm{ST}} & =\text { eksergi uap yang dihasilkan boiler (MW) } \\
\mathrm{E}_{\mathrm{FG}} & =\text { eksergi gas hasil pembakaran (MW) } \\
\mathrm{E}_{\mathrm{ASH}} & =\text { eksergi abu (MW) } \\
\mathrm{E}_{\mathrm{VH}} & =\text { eksergi bahan mudah menguap (MW) } \\
\mathrm{I}_{\mathrm{HRSG}} & =\text { destruksi eksergi dari HRSG (MW) }
\end{array}
$$

Eksergi kimia bahan bakar padat (MSW) dengan komponen $\mathrm{C}, \mathrm{H}, \mathrm{O}$ dan $\mathrm{N}$ diberikan oleh persamaan $19^{(10)}$

$$
E_{M S W}=m_{M S W} \times \beta \times L H V .
$$

Dimana $\beta$ adalah konstanta eksergi yang dinyatakan oleh persamaan berikut ${ }^{(10)}$.

$\beta=1,0437+0,0140 \times \frac{H}{C}+0,0968 \times \frac{O}{C}+0,0467 \times \frac{N}{C} .$.

\subsubsection{Sistem Turbin - Generator}

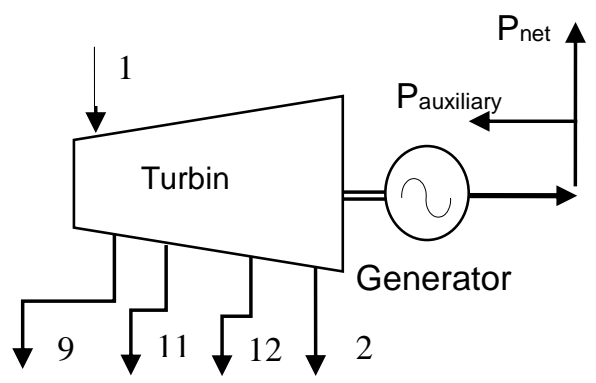

Gambar 5. Turbin-Generator

Laju aliran massa uap masuk turbin uap adalah:

$$
m_{1}=m_{2}+m_{9}+m_{11}+m_{12}
$$

Daya yang dihasilkan turbin diberikan oleh persamaan:

$$
\begin{aligned}
& P_{t}=m_{1}\left(h_{1}-h_{9}\right)+\left(m_{1}-m_{9}\right)\left(h_{9}-h_{11}\right)+ \\
& \left(m_{1}-m_{9}-m_{11}\right)\left(h_{11}-h_{12}\right)+\left(m_{1}-m_{9}-m_{11}-m_{12}\right) \\
& \left(h_{12}-h_{2}\right) \ldots \ldots \ldots \ldots \ldots \ldots \ldots \ldots \ldots \ldots \ldots \ldots \ldots \ldots \ldots \ldots \ldots \ldots \ldots \ldots \ldots \ldots \ldots \ldots \ldots \ldots \ldots \ldots \ldots
\end{aligned}
$$

Daya kotor (gross power) yang dihasilkan generator adalah:

$$
P_{\text {gross }}=P_{t} \times \eta_{m} \times \eta_{g}
$$

Keluaran daya bersih dapat dinyatakan dengan persamaan:

$$
P_{n e t}=P_{\text {gross }}-P_{a}
$$

Berdasarkan Gambar 6 persamaan neraca eksergi adalah :

$$
E_{1}=P_{\text {GROSS }}+E_{2}+E_{9}+E_{11}+E_{12}+I_{\text {STEAMTURBINE }}
$$

Dimana $E_{1}$ adalah eksergi uap masuk turbin, $P_{\text {GROSS }}$ adalah eksergi dari tenaga listrik yang dihasilkan generatot, $E_{2}$ eksergi uap keluar turbin, $E_{9}, E_{11}, E_{12}$ masing-masing eksergi uap ekstraksi dari turbin dan ISTEAM TURBINE adalah destruksi eksergi dari sistem turbin uap.

$$
\begin{aligned}
& E_{5} .=m_{5} \times\left[\left(h_{5}-h_{0}\right)-T_{0} \times\left(s_{5}-s_{o}\right)\right] \ldots \\
& E_{9}=m_{9} \times\left[\left(h_{9}-h_{0}\right)-T_{0} \times\left(s_{9}-s_{o}\right)\right] \ldots \\
& m_{5}=m_{9} \ldots \ldots \ldots \ldots \ldots \ldots \ldots \ldots \ldots \ldots \ldots \ldots \ldots \ldots \ldots \ldots \ldots \ldots \ldots \ldots \ldots \ldots \ldots \ldots
\end{aligned}
$$




\subsubsection{Sistem Kondensor}

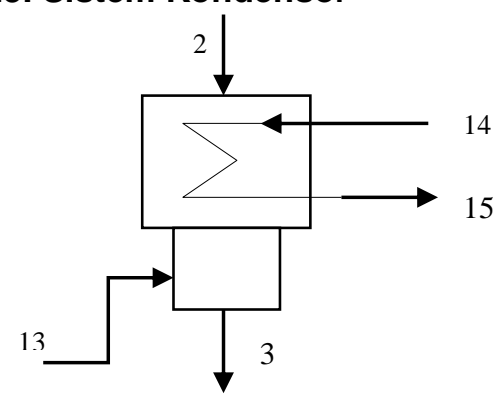

Gambar 6. Sistem Kondensor

Proses kondensasi uap dalam system kondensor dapat dilihat pada gambar 7 . Persamaan neraca masa, neraca energi dan neraca eksergi diberikan oleh persamaanpersamaan berikut :

$m_{2}+m_{13}=m$

$m_{2} \times h_{2}+m_{13} \times h_{13}=m_{3} \times h_{3}$

$E_{2}+E_{13}+E_{14}=E_{3}+E_{15}+I_{\text {CONDENSER }}$

Keterangan:

$\mathrm{E}_{2}$ eksergi uap keluar turbin

$\mathrm{E}_{3}$ eksergi kondensate dari econdenser

$E_{14}$ dan $E_{15}$ eksergi air pendingin,

$\mathrm{E}_{13}$ eksergi drain keluar LPH

Icondenser adalah ireversibilitas dari sistem kondenser.

\subsubsection{Sistem LPH (Low Pressure Heater)}

$m_{12} \times h_{12}+m_{4} \times h_{4}=m_{5} \times h_{5}+m_{13} \times h_{13}$

$E_{12}+E_{4}=E_{5}+E_{13}+I_{L P H}$

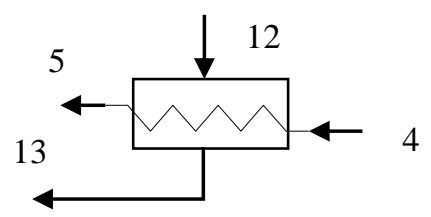

Gambar 7. Sistem Low Pressure Heater

\subsubsection{Sistem Dearator}

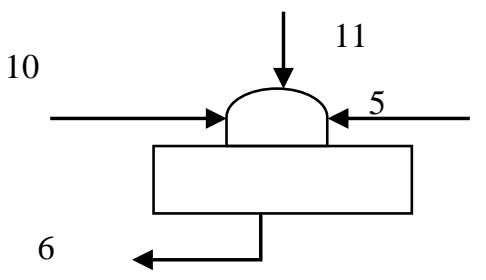

Gambar 8. Sistem Deaerator

$m_{11} \times h_{11}+m_{5} \times h_{5}+m_{10} \times h_{10}=m_{6} \times h_{6}$.

$m_{6}=m_{5}+m_{10}+m_{11}$
$E_{10}+E_{5}+E_{11}=E_{6}+I_{D E A}$

\subsubsection{Sistem Boiler Feed Pump}

Daya yang dibutuhkan untuk menggerakkan pompa diberikan oleh persamaan:

$P_{B F P}=m_{6}\left(h_{7}-h_{6}\right)$. adalah :

Dari gambar 9 persamaan neraca eksergi $E_{6}+P_{B H P}=E_{7}+I_{B H P}$

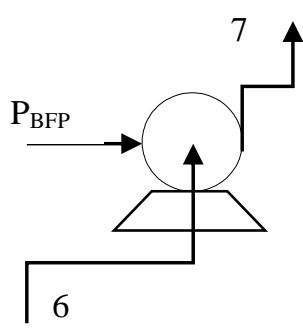

Gambar 9. Sistem Boiler Feed Pump

2.4.7 Sistem HPH (High Pressure Heater)

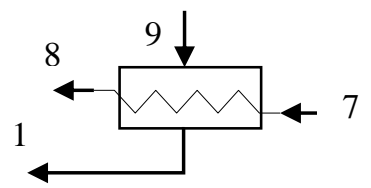

Gambar 10. Sistem High Pressure Heater

Dari gambar 10 persamaan neraca energy dan eksergi diberikan pada persamaan 38 dan 39.

$m_{7} \times h_{7}+m_{9} \times h_{9}=m_{8} \times h_{8}+m_{10} \times h_{10}$

$E_{7}+E_{9}=E_{8}+E_{10}+I_{H P H}$

\section{HASIL DAN PEMBAHASAN}

Dari Tabel 6 dan gambar Gambar 12 dapat dilihat destruksi eksergi yang terjadi pada setiap komponen dari PLTSa. Destruksi eksergi atau disebut irreversibility adalah parameter penting yang digunakan dalam analisa eksergi, karena parameter ini memperlihatkan dengan jelas ketidakefisiensian suatu komponen sistem termal. Destruksi eksergi yang terbesar terjadi didalam sistem Insinerator dan boiler sebesar 56,53\%. Disamping karena MSW mengandung abu dan zat-zat yang mudah menguap (Volatile Matters). Destruksi eksergi yang terjadi pada boiler juga disebabkan tidak efisiennya transfer kalor dari gas hasil pembakaran MSW ke fluida kerja, penurunan tekanan yang terjadi di dalam boiler dan kerugian kalor karena radiasi dan konduksi antara boiler dan lingkungan. 
Tabel 6. Destruksi Eksergi PLTSa

\begin{tabular}{lcc}
\hline Komponen & $\begin{array}{c}\text { Destruksi } \\
\text { Eksergi Exergy } \\
\text { Destruction) } \\
(\mathrm{kW})\end{array}$ & $\begin{array}{c}\text { Exergy } \\
\text { Destruction } \\
(\%)\end{array}$ \\
\hline Boiler & 1.4816 & $24,47 \%$ \\
\hline Abu & 1.4121 & $23,32 \%$ \\
\hline Gas Buang & 5.171 & $8,54 \%$ \\
\hline $\begin{array}{l}\text { Turbin } \\
\text { Generator }\end{array}$ & 5.260 & $8,69 \%$ \\
\hline Kondensor & 2.292 & $3,79 \%$ \\
\hline $\begin{array}{l}\text { Pompa } \\
\text { Kondensat }\end{array}$ & 3,37 & $0,01 \%$ \\
\hline LP Heater & 166,6 & $0,28 \%$ \\
\hline Dearator & 172,6 & $0,29 \%$ \\
\hline $\begin{array}{l}\text { Pompa } \\
\text { Pengisi Ketel }\end{array}$ & 52,42 & $0,09 \%$ \\
\hline HP Heater & 104.96 & $0.17 \%$ \\
\hline
\end{tabular}

Dari Tabel 7 dapat dilihat bahwa total eksergi yang masuk ke insenerator adalah 60.560,54 kW yaitu 58.242,45 kW berasal dari MSW dan 2.318,08 kW berasal dari udara pembakaran. Sebanyak $14121,85 \mathrm{~kW}(23,32 \%)$ dari total eksergi hilang dalam bentuk abu, 5.171,47 kW $(8,54 \%)$ dibawa gas buang (flue gas) melalui cerobong. Efisiensi dari system Incenerator - Boiler adalah $64,10 \%$ dimana destruksi eksergi sebesar $14.816,56 \mathrm{~kW} .(24,47 \%)$

Tabel 7. Ringkasan analisa eksergi dari system Insinerator-Boiler.

\begin{tabular}{|c|c|}
\hline Keterangan & Nilai \\
\hline $\begin{array}{lll}\text { Eksergi sampah pada inlet } \\
\text { Insinerator }(\mathrm{kW})\end{array}$ & $58.242,46$ \\
\hline $\begin{array}{l}\text { Eksergi udara inlet Insinerator } \\
(\mathrm{kW})\end{array}$ & $2.318,08$ \\
\hline $\begin{array}{l}\text { Eksergi Flue Gas pada outlet } \\
\text { HRSG (kW) }\end{array}$ & $5.171,47$ \\
\hline $\begin{array}{l}\text { Eksergi abu outlet Insinerator } \\
\text { (kW) }\end{array}$ & $1.4121,85$ \\
\hline $\begin{array}{l}\begin{array}{l}\text { Eksergi air inlet Economizer } \\
(\mathrm{kW})\end{array} \\
\end{array}$ & $3.251,21$ \\
\hline $\begin{array}{l}\text { Eksergi steam Outlet HRSG } \\
(\mathrm{kW})\end{array}$ & $2.9701,85$ \\
\hline $\begin{array}{lll}\begin{array}{l}\text { Irreversibilitas } \\
(\mathrm{kW})\end{array} & \text { dalam } & \text { HRSG } \\
\end{array}$ & $14.816,57$ \\
\hline $\begin{array}{lll}\text { Overall } & \text { efficiency } & \text { Sistem } \\
\text { Insinerator -HRSG (\%) } & \\
\end{array}$ & 64.10 \\
\hline
\end{tabular}

Tabel 8. Ringkasan analisa eksergi dari system turbin -generator.

\begin{tabular}{ll}
\hline \multicolumn{1}{c}{ Keterangan } & \multicolumn{1}{c}{ Nilai } \\
\hline Inlet turbine $(\mathrm{kW})$ & $21.395,22$ \\
\hline Outlet Steam Extraction 1 & $1.606,27$ \\
\hline
\end{tabular}

\begin{tabular}{ll}
\hline$(\mathrm{kW})$ & \\
\hline $\begin{array}{l}\text { Outlet Steam Extraction } 2 \\
(\mathrm{~kW})\end{array}$ & $1.258,30$ \\
\hline $\begin{array}{l}\text { Outlet Steam Extraction } 3 \\
\text { (kW) }\end{array}$ & 657,11 \\
\hline Outlet Steam Turbine $(\mathrm{kW})$ & $3.187,81$ \\
\hline Exergy drop $(\mathrm{kW})$ & $18.207,41$ \\
\hline Gross turbine power $(\mathrm{kW})$ & $9.857,87$ \\
\hline Gross electrical power $(\mathrm{kW})$ & $9.425,38$ \\
\hline Exergy destruction $(\mathrm{kW})$ & $5.260,36$ \\
\hline Efisiensi Eksergi $(\%)$ & 67,13 \\
\hline
\end{tabular}

Tabel 9. Ringkasan analisa eksergi dari system kondensor.

\begin{tabular}{ll}
\hline \multicolumn{1}{c}{ Keterangan } & \multicolumn{1}{c}{ Nilai } \\
\hline Steam Turbine Outlet $(\mathrm{kW})$ & 3187.81 \\
\hline Condensor outlet $(\mathrm{kW})$ & 135.71 \\
\hline $\begin{array}{l}\text { Drain LP Heater pada inlet } \\
\text { kondenser }(\mathrm{kW})\end{array}$ & 15.22 \\
\hline Cooling Water Inlet $(\mathrm{kW})$ & 4499.32 \\
\hline Cooling Water oulet $(\mathrm{kW})$ & 5273.67 \\
\hline Ireversibility Condensor $(\mathrm{kW})$ & 2292.97 \\
\hline Exergy Efficiency $(\%)$ & $25.24 \%$ \\
\hline
\end{tabular}

Eksergi total yang diterima pada sisi masuk turbin adalah 21.395,22 kW. Penurunan eksergi melalui turbin uap adalah sebesar 18.207,41 kW dan tenaga kotor yang dihasilkan oleh turbin sebesar $9.857,87 \mathrm{~kW}$, efisiensi eksergi turbin uap sebesar $67,13 \%$. Dari Tabel 8 dapat dilihat bahwa total eksergi uap keluar turbin dan masuk ke kondensor adalah sebesar 3.187,81 kW

Pada sistem turbin-generator terjadi destruksi eksergi sebesar 5.260,36 kW (8,69 \%) hal ini terjadi karena proses termodinamis yang terjadi di dalam turbin adalah ekspansi irreversible sehingga memberikan kontribusi destruksi eksergi berupa perkalian temperatur lingkungan dan perubahan entropi di dalam turbin ( $T_{0} \times \Delta \mathrm{s}$ ). Pada sistem turbin generator terjadi juga Ireversibilitas eksternal berupa gesekan mekanik pada sistem transmissi dan disistem generator.

Meskipun dalam kondensor terjadi kehilangan maupun destruksi eksergi namun ini nampak lebih kecil dibandingkan dengan tenaga yang dilakukan oleh turbin uap. Dari Tabel 6 dapat dilihat bahwa destruksi eksergi dalam kondensor hanya 3,79\%, ini berbeda dengan analisa energi dimana kerugian energi terbesar di sistem PLTU terjadi di kondensor dalam bentuk energi dialirkan ke lingkungan ${ }^{(10)}$. Tabel 9 memperlihatkan "irreversibility" yang terjadi di kondensor adalah 2292,97 kW dengan efisiensi eksergi dari kondensor adalah $24,24 \%$. 


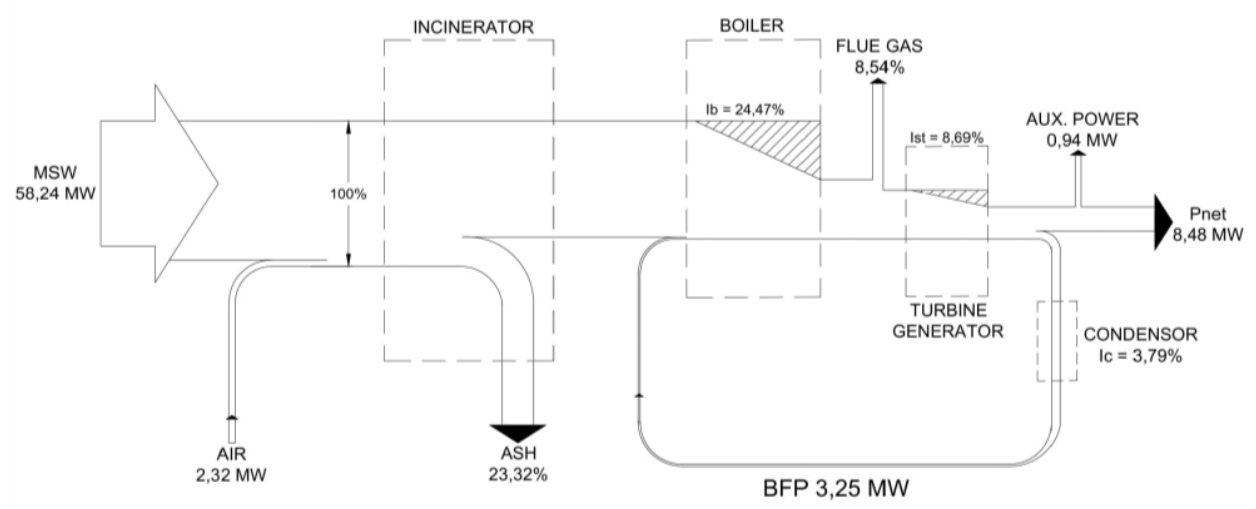

Gambar 11. Diagram Grassman PLTSa

Tabel 10. Ringkasan analisa eksergi dari system Pompa Kondensat

\begin{tabular}{ll}
\hline \multicolumn{1}{c}{ Keterangan } & \multicolumn{1}{c}{ Nilai } \\
\hline Condensor outlet (kW) & 135,71 \\
\hline Condensate Pump outlet (kW) & 145,30 \\
\hline Condensate Pump Power $(\mathrm{kW})$ & 12,96 \\
\hline Ireversibility Condensate Pump & \\
(kW) & 3,37 \\
\hline Exergy Efficiency $(\%)$ & 73,97 \\
\hline
\end{tabular}

Tabel 10 dan tabel 13 masing-masing memperlihatkan parameter kinerja dari Pompa Kondensat dan Pompa Pengisi Ketel. Irreversibility yang terjadi pada pompa kondensat dan pompa pengisi ketel masing-masing 3,37 KW dan $52,42 \mathrm{~kW}$. Efisiensi eksergi dari pompa kondensat dan pompa pengisi ketel masing-masing $73,97 \%$ dan $59,69 \%$.

Tabel 11. Ringkasan analisa eksergi dari system LP Heater

\begin{tabular}{lc}
\hline \multicolumn{1}{c}{ Keterangan } & Nilai \\
\hline Outlet Drain LP Heater (kW) & 15,22 \\
\hline Outlet Condensate Pump (kW) & 145,30 \\
\hline Steam Extraction 3 memasuki & \\
LPHeater (kW) & 680,48 \\
\hline Air pada inlet Deaerator (kW) & 643,95 \\
\hline Ireversibility LPH (kW) & 166,60 \\
\hline Exergy Efficiency $(\%)$ & $74,96 \%$ \\
\hline
\end{tabular}

Tabel 12. Ringkasan analisa eksergi dari system Dearator

\begin{tabular}{ll}
\hline \multicolumn{1}{c}{ Keterangan } & \multicolumn{1}{c}{ Nilai } \\
\hline Air pada inlet Deaerator $(\mathrm{kW})$ & 643,95 \\
\hline Steam Extraction 2 memasuki & \\
Deaerator $(\mathrm{kW})$ & 1248,88 \\
\hline Outlet Drain HP Heater $(\mathrm{kW})$ & 185,67 \\
\hline Air pada outlet Deaerator $(\mathrm{kW})$ & 1905,84 \\
\hline Ireversibility Deaerator $(\mathrm{kW})$ & 172,66 \\
\hline Exergy Efficiency $(\%)$ & $91,69 \%$ \\
\hline
\end{tabular}

Tabel 13. Ringkasan analisa eksergi dari system Pompa Pengisi Ketel

\begin{tabular}{ll}
\hline Keterangan & Nilai \\
\hline Air pada outlet Deaerator (kW) & $1,905,84$ \\
\hline Air pada outlet FWP $(\mathrm{kW})$ & $1,983,46$ \\
\hline Umpan air Pump Power (kW) & 130,04 \\
\hline $\begin{array}{l}\text { Ireversibility Feed Water Pump } \\
\text { (kW) }\end{array}$ & 52,42 \\
\hline Exergy Efficiency $(\%)$ & $59,69 \%$ \\
\hline
\end{tabular}

Pada Tabel 11, 12 dan 14 dapat dilihat parameter kinerja dari peralatan pemanasan air umpan. Efisiensi eksergi dari LPH, Deaerator dan $\mathrm{HPH}$ masing-masing 74,96\% , 91,69\% dan $92,57 \%$. Kerugian eksergi yang terjadi di LPH, Deaerator dan $\mathrm{HPH}$ relatif kecil yaitu masingmasing 166,60 kW, 172,66 kW dan 104,96 kW .

Tabel 14. Ringkasan analisa eksergi dari system HP Heater

\begin{tabular}{ll}
\hline \multicolumn{1}{c}{ Keterangan } & \multicolumn{1}{c}{ Nilai } \\
\hline Keluaran HP Heater outlet $(\mathrm{kW})$ & 185,67 \\
\hline Air pada FWP outlet $(\mathrm{kW})$ & $1.943,82$ \\
\hline $\begin{array}{l}\text { Steam Extraction1 memasuki HP } \\
\text { Heater }(\mathrm{kW})\end{array}$ & $1.598,01$ \\
\hline Air pada inlet Economizer $(\mathrm{kW})$ & $3.251,21$ \\
\hline Ireversibility HPH $(\mathrm{kW})$ & 104,96 \\
\hline Exergy Efficiency $(\%)$ & $92,57 \%$ \\
\hline
\end{tabular}

Dari Tabel 15 dapat dilihat bahwa efisiensi eksergi keseluruhan pembangkit listrik tenaga uap berbahan bakar sampah padat kota (PLTSa) didapat $14,01 \%$ dengan mengacu pada eksergi total yang tersedia pada sisi masuk Insenerator. Daya generator kotor yang dihasilkan sebesar $9425,37 \mathrm{~kW}$, dengan daya pemakaian sendiri 
(Auxiliarry Power) sebesar 942,54 kW sehingga data listrik yang dihasilkan adalah $8.482,83 \mathrm{~kW}$.

Tabel 15. Analisa eksergi keseluruhan pembangkit

\begin{tabular}{|c|c|}
\hline Keteangan & Nilai \\
\hline Total eksergi tersedia(kW) & $60.560,54$ \\
\hline Gross electrical power (kW) & $9.425,37$ \\
\hline $\begin{array}{l}\text { Auxiliarry electric consumption } \\
\text { (kW) }\end{array}$ & 942,54 \\
\hline $\begin{array}{l}\text { Net Electrical power } \\
\text { production }(\mathrm{kW})\end{array}$ & $8.482,83$ \\
\hline Overall exergy efficiency (\%) & $14,01 \%$ \\
\hline
\end{tabular}

Apabila kapasitas faktor diasumsikan $80 \%$ maka energy listrik yang dihasilkan PLTSa setahun adalah "0,8 $\times 8.482,83 \mathrm{~kW} \times 24$ jam/hari $\times 365$ hari/tahun $=59.447 .673 \mathrm{kWh} /$ tahun dan ini mengurangi timbunan sampah sebanyak 660 ton MSW/hari $\times 365=$ ton $M S W /$ tahun $=240.900$ ton MSW/tahun. Pengoperasian PLTSa selama 20 tahun akan mampu mengurangi sampah sebanyak 4.818.000 ton. Berkurangnya jumlah sampah tersebut tentu berkontribusi pula dalam mengurangi emisi $\mathrm{CO}_{2}$ akibat adanya tumpukan sampah di TPA.

Kerugian akibat emisi $\mathrm{CO}_{2}$ dari tumpukan sampah dapat dinilai menggunakan Social Cost of Carbon (SCC). Nilai SCC berdasarkan kepada kerugian yang harus ditanggung masyarakat secara global terkait penurunan produktivitas pertanian, kesehatan, kerusakan akibat meningkatnya intensitas banjir dan berkurangnya nilai dari jasa lingkungan. Jadi dapat disimpulkan bahwa ada manfaat ekonomi yang diperoleh akibat reduksi emisi $\mathrm{CO}_{2}$ sebagai konsekuensi dibangunnya PLTSa berkapasitas 660 ton MSW/hari.

\section{KESIMPULAN}

Dari analisa eksergi yang telah dilakukan untuk PLTSa dapat diketahui lokasi dan jumlah kerugian eksergi, limbah dan penghancuran eksergi dalam proses yang berbeda telah diindikasikan. Selain itu, analisis eksergi memungkinkan tingkat "thermodynamic inefficiency" untuk setiap proses dari PLTSa dapat ditentukan. Kerugian eksergi utama ditemukan terjadi di sistem Insinerator-Boiler, turbin, kondensor, heater dan pompa.

Dari hasil analisa eksergi diatas dapat simpulkan bahwa eksergi total yang tersedia pada sisi masuk Insinerator adalah adalah $60.560,54 \mathrm{~kW}$ yaitu 58.242,45 kW berasal dari MSW dan 2.318,08 kW berasal dari udara pembakaran. Selain itu, dengan pembakaran 660 ton/hari MSW pada sistem PLTSa dihasilkan daya generator
9425,36 kW dengan pemakaian sendiri (Auxiliarry Power) sebesar $942,54 \mathrm{~kW}$ sehingga daya listrik bersih yang dihasilkan adalah 8.482,83 kW.

Pembangunan PLTSa menghaslkan energi listrik 59.447.673 kWh/tahun akan mengurangi timbunan sampah sebanyak 240,900 ton sampah/tahun, sehingga berkontribusi dalam mengurangi emisi $\mathrm{CO}_{2}$ akibat adanya tumpukan sampah di TPA.

Efisiensi eksergi keseluruhan dari PLTSa adalah $14,01 \%$ yang dihitung dengan acuan eksergi total yang masuk Insenerator. Efisiensi eksergi dari sistem turbin generator $86,21 \%$ sedangkan eisiensi eksergi dari sistem kondenser adalah 78,48\%.Destruksi eksergi yang terbesar terjadi didalam sistem Insinerator dan boiler sebesar $56,53 \%$

\section{DAFTAR PUSTAKA}

1) Anonimous. (2018). Jakarta Dalam Angka 2018, Badan Pusat Statistik Provinsi DKI Jakarta.

2) Anonimous. (2018). Peraturan Presiden No. 35 tahun 2018 tentang Percepatan Pembangunan Instalasi Pengolahan Sampah Menjadi Energi Listrik Berbasis Teknologi Ramah Lingkungan di Provinsi DKI Jakarta, Kota Tangerang, Kota Tangerang Selatan, Kota Bekasi, Kota Bandung, Kota Semarang, Kota Surakarta, Kota Surabaya, Kota Makasar, Kota Denpasar, Kota Palembang dan Kota Manado.

3) Anonimous. (2015). Peraturan Menteri ESDM No. 44 tahun 2015 tentang Pembelian Tenaga Listrik oleh PT PLN (Persero) dari Pusat Listrik Tenaga Sampah (PLTSa)

4) Anonimous. (2015). 21' Century Advanced Concept for Waste Fired Power Plant, Babcock \& Wilcox.

5) Adrian Bejan, George Tsatsaronis \& Michael Moran. (1996). Thermal Design \& Optimization, John Wiley \& Sons, Inc, New York USA.

6) Amirabedin Ehsan \& M. Zeki Yilmazoglu. (2011). Design and Exergy Analysis of Thermal Power Plant Using Different Types of Turkish Lignite, International Journal of Thermodynamics, Vol 14 No3 pp 125-133.

7) Arthur M Omari \& Karoli N Njau, September. (2015). Mass and Energy Balance For Fixed Bed Incinerators- A case of a locally designed incinerator in Tanzania, Journal of Multidisciplinary Engineering Science and 
Technology (JMEST), Vol. 2 Issue 9, pp 23652373

8) Chattopadhy, P. (2006). Boiler Operation Engineering, Tata McGraw Hill New Delhi.

9) Gong, M., \& Wall, G. (1997). On exergetics, economics and optimization of technical processes to meet environmental conditions. Proceedings of the conference: Thermodynamic analysis and improvement of energy systems, Beijing, China, 453-460.

10) Jan Szargut, David. R. Morris \& Frank. R. Steward (1988). Exergy Analysis of Thermal, Chemical, and Metallurgical Processes, Hemisphire Publishing Corporation, New York USA.

11) Kaushik, S.C., Siva Reddy, V. \& Tyagily, S.K., (2011). Energy and Exergy Analyses of Thermal Power Plant: A Review, Renewable and Sustanable Energy Reviews.

12) Kotas, T.J,. (1995). The exergy method of thermal plant analysis. Krieger Publishing Co. Ltd. Florida, USA.
13) Moran-Shapiro. (1999). Fundamental of Engineering Thermodynamic, 4th ed, Willey, USA.

14) Nag, PK (2002). Power Plant Engineering nd Edition, Mc Graw Hill

15) Rosen, M.\& Dincer, I (2008). Exergy as the confluence of energy, environment and sustainable development. Internat. J. on Exergy, 1, 3-13.

16) Syamsir, A. Muin (1988). Pesawat- Pesawat Konversi Energi 1 (Ketel Uap), Rajawali Press, Jakarta.

17) Ujam, A.J \& Ebob, F. (2012). Thermal Analysis of a Small Scale Municipal Solid Waste Fired Steam Generator: Case Study of Enugu State, Nigeria, Journal of Energy Technologies and Policy, Vol 2 No 5.

18) Walter $R$ Niesen (2002). Combustion and Incineration Processes, Third Edition, Marcel Dekker, Inc, New York. 